\title{
RANCANG BANGUN SISTEM PENGUKURAN KESELARASAN TEKNOLOGI DAN BISNIS UNTUK PROSES AUDITING
}

\author{
Damayanti', Dyah Ayu Megawati ${ }^{2)}$, Dwi Santia ${ }^{3)}$, Indra Kurniawan ${ }^{4)}$ \\ ${ }^{1223)}$ Sistem Informasi, Universitas Teknokrat Indonesia \\ ${ }^{4)}$ Teknik Komputer, Universitas Teknokrat Indonesia \\ Jl. H.ZA Pagaralam, No 9-11, Labuhanratu,Bandarlampung \\ Email :damayanti@teknokrat.ac.id ${ }^{1}$,dyahayumegawaty@teknokrat.ac.id ${ }^{2}$,dwisantil@gmail.com ${ }^{3)}$
}

\begin{abstract}
Abstrak
Teknologi informasi saat ini berkembang sangat pesat dan merambah dalam berbagai bidang terutama dalam perusahaan. Pada saat ini teknologi memiliki peran penting dalam pengelolaan bisnis dalam perusahaan sehingga perlu dilakukan penyelarasan terhadap penerapan teknologi dan bisnis. Penyelarasan strategi teknologi dan bisnis merupakan strategi yang digunakan untuk memastikan bahwa adanya kesesuaian antara penerapan tekologi dengan tujuan bisnis yang telah direncanakan. Pengukuran keselarasan teknologi dan bisnis yang dilakukan auditor masih dilakukan secara manual yaitu perhitungan hasil kuisioner dari jawaban responden dihitung satu persatu menggunakan kalkulator sehingga perhitungan rentan terjadi kesalahan. Penelitian ini bertujuan untuk membuat rancang bangun sistem pengukuran keselarasan teknologi dan bisnis menggunakan model Lufman yang diharapkan dapat mempermudah proses auditing dalam organisasi karena perhitungan hasil kuisinoner dari jawaban responden dapat dilakukan secara otomatis.
\end{abstract}

Kata kunci: Audit, teknologi, bisnis.

\section{Pendahuluan}

Teknologi informasi saat ini berkembang sangat pesat dan merambah dalam berbagai bidang terutama dalam perusahaan (Suryono, Darwis and Gunawan, 2018). Teknologi merupakan inovasi yang menjadi pilihan penting dalam berbagai bidang (Ahdan and Sari, 2020). Teknologi berperan penting dalam perkembangan perusahaan saat ini sehingga teknologi menjadi salah satu penentu keberhasilan dalam memajukan bisnis dalam perusahaan (Sulistiani, 2020). Salahnya satunya adalah teknologi berbasis web. Teknologi Informasi berbasis web diyakini dapat mempermudah dalam pengelolaan organisasi sehingga pekerjaan menjadi lebih efektif dan efisien secara otomatis (Damayanti and Nirmalasari, 2019) serta mempercepat dalam pengolahan data (Elly and Hati, 2020).

Pada saat ini teknologi memiliki peran penting dalam pengelolaan bisnis dalam organisasi sehingga perlu dilakukan penyelarasan terhadap penerapan teknologi dan bisnis. Penyelarasan strategi teknologi dan bisnis merupakan strategi yang digunakan untuk memastikan bahwa adanya kesesuaian antara penerapan teknologi dengan tujuan bisnis yang telah direncanakan. Hal ini menjadi salah satu pusat perhatian penting dalam penelitian (Alraggas and Alzayed, 2014). Pada penelitian sebelumnya (Chumo, 2016) bahwa penyelarasan strategi teknologi dan bisnis merupakan hal penting bagi perusahaan untuk memperoleh value atau manfaat atas teknologi informasi yang telah diinvestasi. Hal yang sama juga pada penelitian (Damayanti, Megawaty and Santia, 2019) bahwa pengukuran strategi bisnis dan teknologi merupakan hal yang penting bagi organisasi dalam menjalankan organisasinya. Pada penelitian (Ashshidiqy and Ali, 2019) menyatakan bahwa perusahaan menginkan adanya keselarasan antara strategi TI dan bisnis. Keselarasan IT dan bisnis merupakan hal yang utama dalam sebuah perusahaan baik perusahaan yang kecil, perusahaan menengah bahkan perusahaan yang besar dalam mencapai tujuan (Airlangga, 2018).

Dari beberapa penelitian sebelumnya yang terkait pengukuran keselarasan teknologi dan bisnis merupakan hal yang penting dilakukan dalam perusahaan atau organisasi. Hasil tingkat keselarasan teknologi dan bisnis berdasarkan hasil kuesioner yang disebarkan kepada responden. Berdasarkan kajian penelitian-penelitian sebelumnya dalam melakukan pengukran keselarasan strategi teknologi dan bisnis dalam melakukan perhitungan hasil kuesioner cenderung masih dilakukan secara manual yaitu perhitungan hasil kuisioner dari jawaban responden dihitung satu persatu oleh auditor menggunakan kalkulator sehingga perhitungan rentan terjadi kesalahan, Dalam mengatasi permasalahan tersebut maka penelitian ini bertujuan untuk membuat rancang bangun sistem pengukuran keselarasan teknologi dan bisnis menggunakan model Lufman (Luftman, 2000). Aplikasi sistem pengukuran keselarasan teknologi dan bisnis dibangun berbasis web yang diharapkan dapat mempermudah proses auditing dalam organisasi karena perhitungan hasil kuisinoner dari jawaban responden dapat dilakukan secara otomatis.

\section{Pembahasan}

\subsection{Tahapan Penelitian}

Tahapan dalam merancang sistem pengukuran keselarasan teknologi dan bisnis peenelitian ini yaitu 
identifikasi masalah, planning, desain, pengkodean, dan pengujian.

\subsection{Pengumpulan Data}

Pengumpulan data yang digunakan yaitu teknik pengumpulan data:

A. Pengamatan (Observasi)

Mengumpulkan data melalui pengamatan langsung dan mencatat secara sistematis terhadap unsur-unsur yang diamati dalam kegiatan alur yang diakukan nyk pengmebangan system yang akan dibangun

B. Kuisioner

Kuisioner digunakan sebagai alat yang digunakan untk mengumpulkan data primer yang diperoleh dari persepsi responden (Pujihastuti, 2010).

C. Wawancara

Melakukan penugumpulan data dengan melakukan tanya jawab langsung kepada respon guna memperoleh informasi yang dibutuhkan (Rosaliza, 2015).

D. Tinjauan Pustaka

Melakukan pengumpulan data dengan mencari sumber penelitian terdahulu atau teori-teori sesuai dengan data yang dibutuhkan.

\subsection{Analiiss Kebutuhan Sistem}

Kebutuhan sistem terbagi menjadi dua yaitu kebutuhan sistem fungsional dan kebutuhan sistem non-fungsional, yang diperlukan untuk mencapai tujuan yang ingin dicapai.

A. Kebutuhan Fungsional

Kebutuhan fungsional adalah kebutuhan-kebutuhan yang memiliki keterkaitan langsung dengan sistem. Kebutuhan fungsional dari aplikasi ini meliputi:

1. Kebutuhan Super Administrator
a. Melakukan login ke dalam sistem
b. Manipulasi data user
c. Manipulasi data kuesioner
d. Manipulasi data profile
e. Melihat data responden
f. Melihat laporan hasil
g. Melakukan logout dari dalam system

2. Kebutuhan Responden
a. Melakukan pendaftaran ke dalam sistem
b. Melakukan login ke dalam sistem
c. Melakukan inputan profile
d. Melihat Informasi tentang profile
e. Mengisi kuesioner ke dalam sistem
f. Melakukan logout dari dalam sistem

3. Kebutuhan Administrator
a. Melakukan login ke dalam sistem
b. Manipulasi data pendaftaran
c. Manipulasi data user
d. Melihat data responden atau profile responden
e. Manipulasi data kuesioner
f. Melihat informasi hasil tingkat keselarasan

g. Melakukan pengaturan periode audit

h. Melakukan logout dari dalam system

4. Kebutuhan Auditor

a. Melakukan login ke dalam sistem

b. Melakukan input profile

c. Melakukan manipulasi data solusi

d. Mengelola laporan hasil akhir

e. Melakukan logout dari dalam system

B. Kebutuhan Non Fungsional

Kebutuhan non-fungional adalah kebutuhan yang tidak secara langsungterkait dengan fitur tertentu di dalam sistem.

1. Keamanan

Sistem aplikasi dan database yang dirancang dilengkapi dengan password dan user name dalam penggunaannya.

2. Perangkat Pengguna Sistem

Dalam sistem yang dibangun di butuhkan perangkat keras (hardware) dan perangkat lunak (software) ada pun perangkat yang dibutuhkan sebagai berikut:

a. Administrator

Hal yang harus dimiliki oleh administrator adalah:

1) Pc/smartphone yang sudah ada software web browser diantaranya Internet Explore, google chrome dan mozilla firefox dalam menjalankan sistem

2) Akses internet

3) Sistem operasi microsoft windows 7

b. Super Administrator

Hal yang harus dimiliki oleh super administrator adalah

1) Pc/smartphone yang sudah ada software web browser diantaranya internet explore, google chrome dan mozilla firefox dalam menjalankan sistem

2) Akses internet

3) Sistem operasi microsoft windows 7

c. Responden

1) Pc/smartphone yang sudah ada software web browser diantaranya internet explore, google chrome dan mozilla firefox dalam menjalankan sistem

2) Akses internet

3) Sistem operasi microsoft windows 7

d. Auditor

1) Pc/smartphone yang sudah ada software web browser diantaranya internet explore, google chrome dan mozilla firefox dalam menjalankan sistem

2) Akses internet

3) Sistem operasi microsoft windows 7

\subsection{Perancangan Sistem}

Perancangan adalah proses dari apa saja dan bagaimana cara mengembangkan sistem baru adapun perancangan 
system menggunakan Unified Modeling Language (UML). UML merupakan notasi yang lengkap untuk membuat visualisasi model suatu sistem. Sistem berisi informasi dan fungsi, namun secara normal digunakan untuk pemodelan sistem komputer (Rosa and M, 2013). Jenis diagram yang digunakan adalah diadgram usecase.

Use case diagram merupakan pemodelan untuk kelakuan (behavior) aplikasi yang akan dibuat. Use case mendeskripsikan sebuah interaksi satu atau lebih aktor dengan sistem yang akan dibuat. Use case digunakan untuk mengetahui fungsi apa saja yang ada didalam sebuah sistem dan siapa saja yang berhak menggunakan fungsi-fungsi itu. Aktor yang terlibat pada system yang akan dibanguan adalah Admin, Responden, Auditor dan Super admin.

1. Admin

Admin adalah yang aktor yang memiliki akses yang dapat megelola menu daftar, mengelola data user, view data responden, view hasil penilaian, mengelola data kuesioner dan mengelola periode yang dapat dilihat pada activity digram berikut:

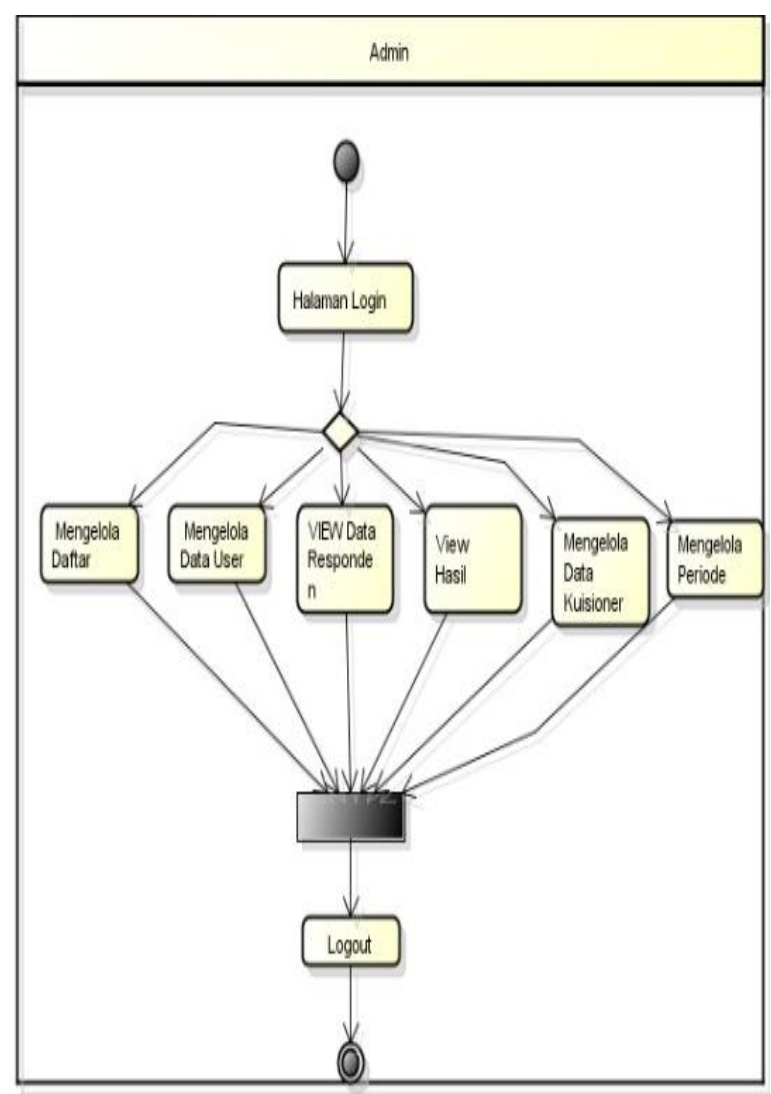

Gambar 1. Actifity Diagram Admin

2. Responden

Responden adalah aktor yang memiliki akses mengisi kuesioner dan view profile yang digambarkan pada activity diagram berikut:

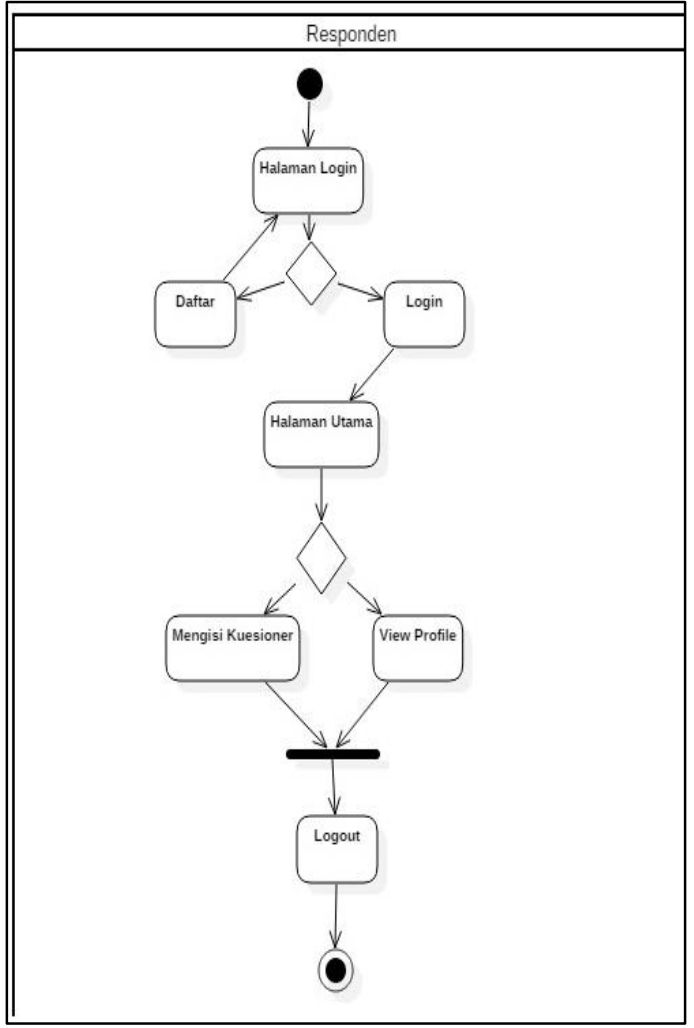

Gambar 2. Actifity Diagram Responden

3. Auditor

Auditor merupakan aktor yang memiliki akses mengelola solusi, mengelola profile, dan membuat laporan hasil perhitungan keselarasan teknologi dan bisnis yang dapat dlilihat pada actifity diagram berikut:

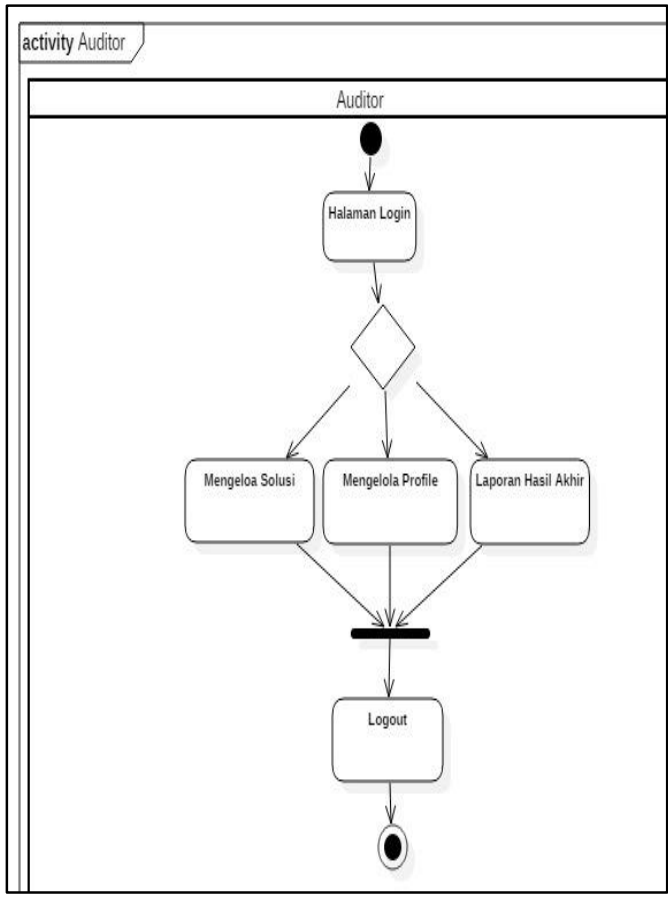

Gambar 4. Actifity Diagram Auditor 


\section{Super Admin}

Super admin merupakan actor yang memiliki akses dapat menglola profile, mengelola data user, view data responen, view laporan hasi perhitungan, dan dapat mengelola data kuesioner yang dapat dilihat pada actifity diagram berikut:

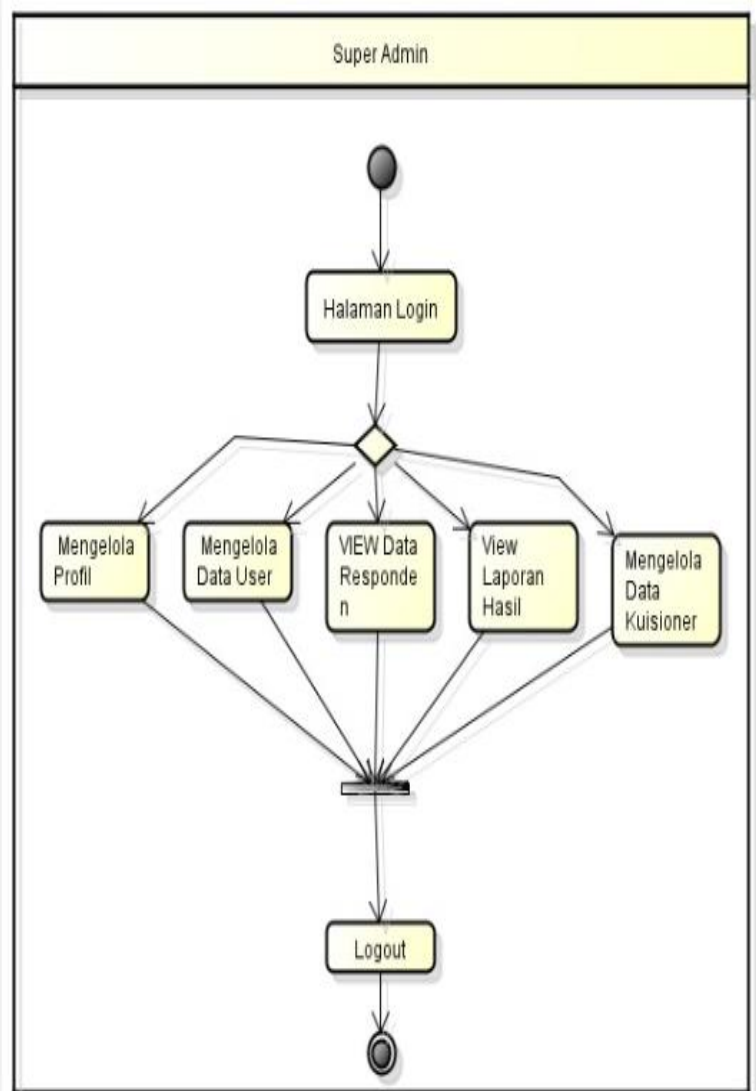

Gambar 5. Actifity Diagram Super Admin

\subsection{Implementasi Sistem}

1. Tampilan Antar Muka Menu Utama

Tampilan menu utama merupakn menu antar muka yang tampil setelah aktor melakukan login. Sub menu yang terpadat pada menu utama terdiri dari sub menu beranda, profile, responden, data kuesioner, data user, laporan hasil, dan setting periode. Menu utama dapat dilihat pada gambar 6 .

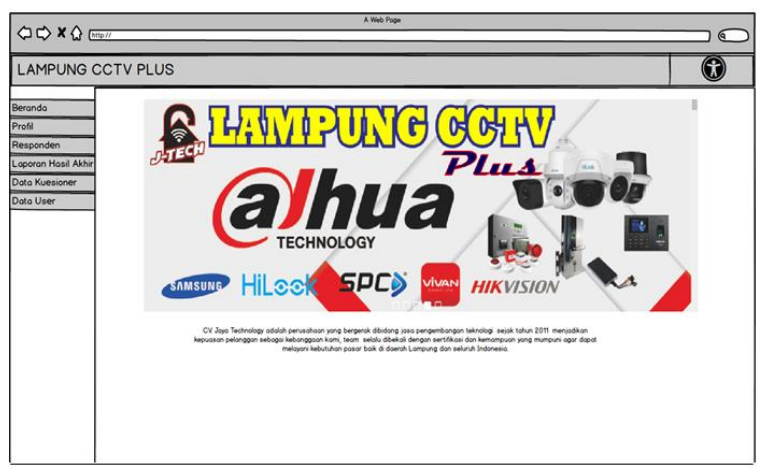

Gambar 6. Tampilan Menu Utama
2. Antar Muka Data Kuesioner

Tampilan antar muka data kuesioner yaitu data yang berisi instrument atau pernyataan-pernyataan yang disediakan system untuk diisi oleh responden dalam menilai tingkat keselarasan teknologi dan bisnis yang mengacu pada instrument model lufman.

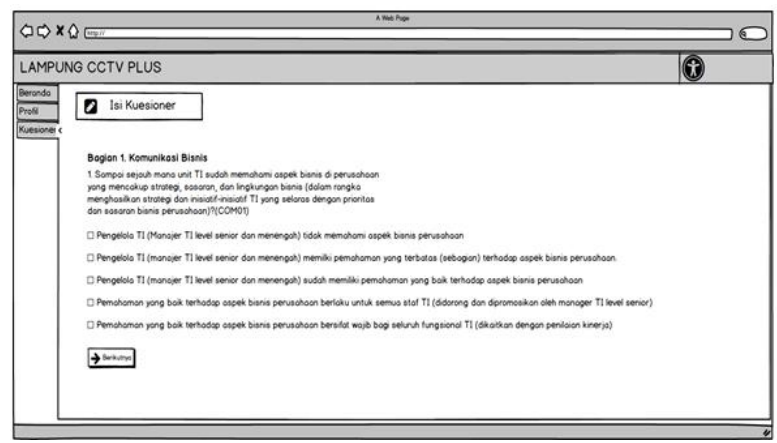

Gambar 7. Menu Data Kuesioner

3. Hasil Perhitungan Keselarasan

Menu hasil keselarasan ini merupakan menu yang menunjukkan hasil perhitungan tingkat keselarasan teknologi dan bisnis berdasarkan penilaian instrument yang dilakukan oleh responden. Hasil perhitungan kuesioner dari responden akan terhitung secara otomatis oleh sistem pada akses auditor.

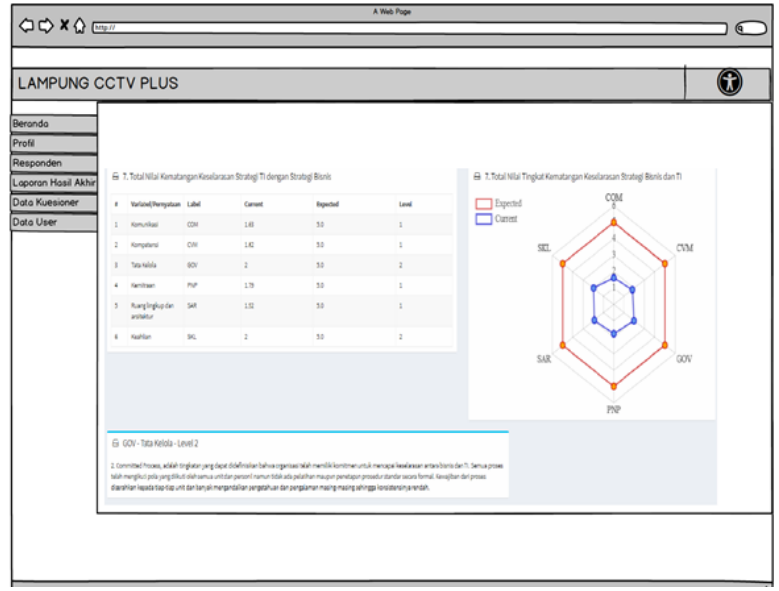

Gambar 7. Tampilan Menu Hasil

4. Menu Solusi

Menu solusi merupakan menu yang diakses oleh auditor untuk memberikan solusi atau masukan kepada perusahaan/organisasi berdasarkan hasil temuan dari perhitungan tingkat keselarasan teknologi dan bisnis yang telah dilakukan. 


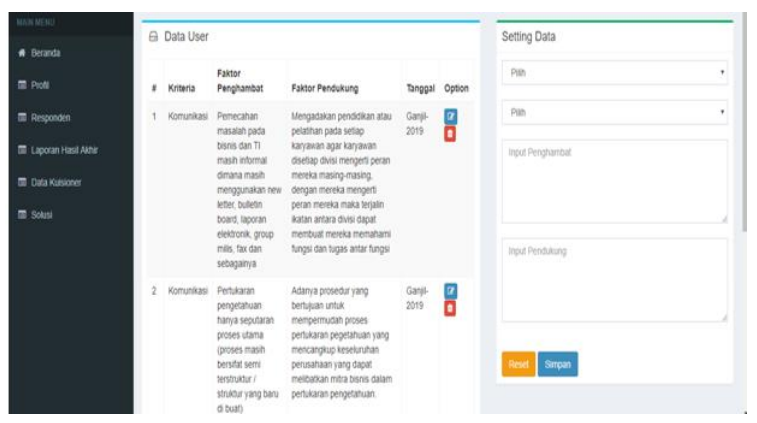

Gambar 8. Tampilan Menu Solusi

\subsection{Pengujian}

Pada tahap ini dilakukan pengujian ssstem yang telah diimplementasikan menggunakan pengujian blackbox. Berikut merupakan hasil pengujian pada sistem pengukuran tingkat keselarasan anatara strategi bisnis dan TI

Tabel 1. Hasil Pengujian Blackbox

\begin{tabular}{|c|c|c|c|}
\hline \multicolumn{4}{|c|}{ Hasil Pengujian Login } \\
\hline $\begin{array}{c}\text { Data } \\
\text { Masukan }\end{array}$ & $\begin{array}{c}\text { Data } \\
\text { Diharapkan }\end{array}$ & $\begin{array}{c}\text { Pengamata } \\
\mathrm{n}\end{array}$ & Kesimpulan \\
\hline $\begin{array}{l}\text { Data } \\
\text { terdaftar } \\
\text { Memasuk } \\
\text { kan } \\
\text { Username } \\
\text { dan } \\
\text { Password. } \\
\text { (Benar) } \\
\end{array}$ & $\begin{array}{l}\text { Tampilkan } \\
\text { menu utama }\end{array}$ & $\begin{array}{ll}\text { Masuk ke } \\
\text { menu } \\
\text { utama }\end{array}$ & $\begin{array}{l}{\left[^{\checkmark}\right] \text { Diterima }} \\
{[\text { ] Ditolak }}\end{array}$ \\
\hline \multicolumn{4}{|c|}{ Hasil Pengujian Log Out } \\
\hline $\begin{array}{l}\text { Data tidak } \\
\text { terdaftar } \\
\text { Memasuk } \\
\text { kan } \\
\text { Username } \\
\text { dan } \\
\text { Password. } \\
\text { (Salah) }\end{array}$ & $\begin{array}{l}\text { Sistem akan } \\
\text { menolak } \\
\text { akses login } \\
\text { dan } \\
\text { menampilka } \\
\text { n pesan } \\
\text { "Gagal } \\
\text { Login". }\end{array}$ & $\begin{array}{l}\text { Mengisi } \\
\text { username } \\
\text { dan } \\
\text { password } \\
\text { salah atau } \\
\text { kosong }\end{array}$ & $\begin{array}{l}{[\sqrt{ }] \text { Diterima }} \\
{[\text { ] Ditolak }}\end{array}$ \\
\hline $\begin{array}{l}\text { Data } \\
\text { kosong } \\
\text { atau tidak } \\
\text { diisi } \\
\text { semua }\end{array}$ & $\begin{array}{l}\text { Sistem akan } \\
\text { menolak } \\
\text { akses login } \\
\text { dan } \\
\text { menampilka } \\
\text { n pesan } \\
\text { "Gagal } \\
\text { Login" }\end{array}$ & $\begin{array}{l}\text { username } \\
\text { dan } \\
\text { password } \\
\text { tidak diisi } \\
\text { (dikosongk } \\
\text { an) }\end{array}$ & $\begin{array}{l}{[\sqrt{ }] \text { Diterima }} \\
{[\text { ] Ditolak }}\end{array}$ \\
\hline \multicolumn{4}{|c|}{ Hasil Pengujian Menu Profile } \\
\hline $\begin{array}{l}\text { Klik Form } \\
\text { Menu } \\
\text { "Profile". }\end{array}$ & $\begin{array}{l}\text { Tampilkan } \\
\text { form Menu } \\
\text { Profile. }\end{array}$ & $\begin{array}{l}\text { Ketika di } \\
\text { klik menu } \\
\text { Profile } \\
\text { maka } \\
\text { sistem akan } \\
\text { langsung } \\
\text { tampil ke } \\
\text { menu } \\
\text { Profile. }\end{array}$ & $\begin{array}{l}{[\sqrt{ }] \text { Diterima }} \\
{[\text { ] Ditolak }}\end{array}$ \\
\hline
\end{tabular}

\begin{tabular}{|c|c|c|c|}
\hline $\begin{array}{l}\text { Klik } \\
\text { tombol } \\
\text { "Simpan } \\
\text { di menu } \\
\text { Profile" }\end{array}$ & $\begin{array}{l}\text { Muncul form } \\
\text { Inputan } \\
\text { Profile. } \\
\text { Dengan } \\
\text { pesan } \\
\text { Berhasil } \\
\text { Merubah } \\
\text { Data” }\end{array}$ & $\begin{array}{l}\text { Ketika di } \\
\text { klik } \\
\text { Simpan di } \\
\text { menu } \\
\text { Profile, } \\
\text { maka } \\
\text { sistem akan } \\
\text { langsung } \\
\text { tampil ke } \\
\text { form } \\
\text { masukan } \\
\text { profile } \\
\text { yang baru } \\
\text { di ubah. }\end{array}$ & $\begin{array}{l}{[\sqrt{ }] \text { Diterima }} \\
{[\text { ] Ditolak }}\end{array}$ \\
\hline \multicolumn{4}{|c|}{ Hasil Pengujian Menu Responden } \\
\hline $\begin{array}{l}\text { Menu } \\
\text { Registrasi }\end{array}$ & $\begin{array}{l}\text { Sistem Akan } \\
\text { melakukan } \\
\text { Pendaftaran } \\
\text { data Calon } \\
\text { User Baru }\end{array}$ & $\begin{array}{l}\text { User harus } \\
\text { mengisi } \\
\text { from } \\
\text { pendaftaran } \\
\text { yang sudah } \\
\text { tersedia di } \\
\text { program }\end{array}$ & $\begin{array}{l}{[\sqrt{ }] \text { Diterima }} \\
\text { [ ] Ditolak }\end{array}$ \\
\hline \multicolumn{4}{|c|}{ Hasil Uji Menu Data Kuesioner } \\
\hline $\begin{array}{l}\text { Klik } \\
\text { tombol } \\
\text { "Buat } \\
\text { Kuisioner } \\
\text { ". }\end{array}$ & $\begin{array}{l}\text { Muncul form } \\
\text { Input Data } \\
\text { Kuisioner. }\end{array}$ & $\begin{array}{l}\text { Ketika di } \\
\text { klik } \\
\text { Tombol } \\
\text { Buat } \\
\text { Kuisioner } \\
\text { responden, } \\
\text { Muncul } \\
\text { form } \\
\text { masukan } \\
\text { data } \\
\text { kuisioner } \\
\text { responden } \\
\text { yang akan } \\
\text { di isi. }\end{array}$ & $\begin{array}{l}{[\sqrt{ }] \text { Diterima }} \\
{[\text { ] Ditolak }}\end{array}$ \\
\hline $\begin{array}{l}\text { Klik } \\
\text { tombol } \\
\text { "Selesai" }\end{array}$ & $\begin{array}{l}\text { Sistem akan } \\
\text { menyimpan } \\
\text { Data } \\
\text { kuisioner } \\
\text { yang telah } \\
\text { diisi dalam } \\
\text { database }\end{array}$ & $\begin{array}{l}\text { Ketika di } \\
\text { klik tombol } \\
\text { Selesai } \\
\text { maka } \\
\text { kuisioner } \\
\text { yang telah } \\
\text { diisi dalam } \\
\text { database }\end{array}$ & $\begin{array}{l}{[\sqrt{ }] \text { Diterima }} \\
{[\text { ] Ditolak }}\end{array}$ \\
\hline \multicolumn{4}{|c|}{ Hasil Uji Menu Auditor } \\
\hline $\begin{array}{l}\text { Klik Form } \\
\text { Menu } \\
\text { "Laporan } \\
\text { Hasil } \\
\text { akhir". }\end{array}$ & $\begin{array}{l}\text { Tampilkan } \\
\text { form menu } \\
\text { Laporan } \\
\text { Hasil akhir } \\
\text { akan } \\
\text { memproses } \\
\text { perhitungan } \\
\text { pengukuran } \\
\text { keselarasan. }\end{array}$ & $\begin{array}{l}\text { Ketika di } \\
\text { klik form } \\
\text { menu } \\
\text { Laporan } \\
\text { Hasil akhir } \\
\text { maka } \\
\text { langsung } \\
\text { tampil ke } \\
\text { menu } \\
\text { Laporan } \\
\text { Hasil akhir. }\end{array}$ & $\begin{array}{l}\sqrt{ }] \text { ] Diterima } \\
{[\text { ] Ditolak }}\end{array}$ \\
\hline $\begin{array}{l}\text { Klik Form } \\
\text { Menu } \\
\text { "Solusi". }\end{array}$ & $\begin{array}{l}\text { Tampilkan } \\
\text { form Solusi } \\
\text { dengan } \\
\text { seeting data } \\
\text { pilihan } \\
\text { memasukan } \\
\text { data solusi. }\end{array}$ & $\begin{array}{l}\text { Ketika di } \\
\text { klik form } \\
\text { menu } \\
\text { Solusi } \\
\text { maka } \\
\text { langsung } \\
\text { tampil ke } \\
\text { menu } \\
\end{array}$ & $\begin{array}{l}{[\sqrt{ }] \text { Diterima }} \\
{[\text { ] Ditolak }}\end{array}$ \\
\hline
\end{tabular}




\section{\begin{tabular}{|l|l|l|l|}
\hline & & Solusi. & \\
\hline
\end{tabular}}

Hasil pengujian blackbox dapat simpulkan bahwa sistem aplikasi yang telah dibangun layak untuk diimplementasikan.

\section{Kesimpulan}

Penelitian ini menghasilkan aplikasi sistem pengkuran tingkat keselarasan teknologi dan bisnis yang dapat mempermudah auditor dalam melakukan proses audit pada sebuah organisasi karena perhitungan hasil kuisinoner dari jawaban responden dapat dilakukan secara otomatis. Hasil pengujian blackbox menunjukkan bahwa sistem layak untuk diimplementasikan. Pengembangan sistem selanjutnya diharapkan saat melakukan pengisian kuisioner menggunakan perkembangan teknologi berbasis android.

\section{UCAPAN TERIMA KASIH}

Penulis mengucapkan terima kasih kepada Kementrian Riset dan Teknologi / Badan Riset dan Inovasi Nasional (KEMENRISTEK/BRIN) yang telah memberi dukungan pendanaan/financial terhadap penelitian ini melalui skema Penelitian Dosen Pemula (PDP) tahun 2020 dengan nomor kontrak 007/UTI/LPPM/E.1.3/VII/2020.

\section{Daftar Pustaka}

AHDAN, S. AND SARI, P. I. 2020, 'Pengembangan Aplikasi Web Untuk Simulasi Simpan Pinjam (Studi Kasus : Bmt L-Risma)', 14(1), pp. 33-40.

AIRLANGGA, G. 2018, 'Mengukur tingkat kematangan keselarasan antara it dan bisnis (studi kasus perusahaan startup digital wilayah jawa)', Jurnal Buana Informatika, 9(2), pp. 53-60. doi: 10.24002/jbi.v9i2.1485.

ALRAGGAS, B. AND ALZAYED, A. 2014 'The Alignment of Information Technology and Business Strategy in the Kuwaiti Companies', International Journal of Computer Applications. doi: 10.2304/elea.2011.8.1.47.

ASHSHIDIQY, N. AND ALI, H. 2019, 'Penyelarasan Teknologi Informasidengan Strategi Bisnis', Jurnal Ekonomi Manajemen Sistem Informasi, 1(1), pp. 51-59. doi: 10.31933/jemsi.v1i1.46.

CHUMO, K. P. 2016, 'Information and Knowledge Management Information Systems Strategic Alignment Maturity Levels: Corporate and Project Implementation Perspectives', Iiste.

DAMAYANTI, D. AND NIRMALASARI, N. 2019, 'Sistem Informasi Manajemen Penggajian dan Penilaian Kinerja Pegawai pada SMK Taman Siswa Lampung', Jurnal Teknologi Informasi dan Ilmu Komputer. doi: 10.25126/jtiik.2019641003.

DAMAYANTI, MEGAWATY, D. A. AND SANTIA, D. 2019, 'Assessment of the Alignment Maturity
Level of Business and Information Technology at CV Jaya Technology', in Proceedings - 2019 International Conference on Computer Science, Information Technology, and Electrical Engineering, ICOMITEE 2019. doi: 10.1109/ICOMITEE.2019.8921103.

ELLY, M. N. AND HATI, K. 2020, 'Sistem Informasi Pembayaran Sumbangan Penunjang Pendidikan (SPP) Santri Pesantren Tahfidz Adh Dhuhaa Tangerang', 20(2), pp. 157-166.

LUFTMAN, J. 2000, 'Assessing Business-IT Alignment Maturity', Communications of the Association for Information Systems. doi: 10.17705/1cais.00414.

PUJIHASTUTI, I. 2010, 'Prinsip Penulisan Kuisioner', Jurnal Agribisnis dan Pengembangan Wilayah, 2(1), pp. 43-56.

ROSA, A. . AND M, S. 2013 'Rekayasa Perangkat Lunak Terstruktur', in Informatika, p. 296.

ROSALIZA, M. 2015. 'Wawancara, Sebuah Interaksi Komunikasi Dalam Penelitian Kualitatif', Jurnal Ilmu Budaya, 11(2), pp. 71-79. doi: 10.31849/jib.v11i2.1099.

SULISTIANI, H. 2020, 'Penerapan Metode Cost And Benefit Analysis Dalam Pengukuran Investasi Teknologi Informasi (Study Kasus: Cv Laut Selatan Jaya) The Application of Cost and Benefit Analysis Methods in Measuring Information Technology Investment (Case Study: CV Laut Sel', 14(1), pp. 54-61.

SURYONO, R. R., DARWIS, D. AND GUNAWAN, S. I. 2018, 'Audit Tata Kelola Teknologi Informasi Menggunakan Framework Cobit 5 (Studi Kasus: Balai Besar Perikanan Budidaya Laut Lampung), Jurnal Teknoinfo. doi: 10.33365/jti.v12i1.38. 